\title{
Fyre med ved, fyre med ved
}

Men først må den hogges - med et potensielt farlig redskap... I to artikler over til sammen 25 sider gjennomgikk professor Harbitz i 1933 åtte tilfeller av fatale økseskader - med svært forskjellig bakgrunn. Professorens grundige rettsmedisinske redegjørelser ble avsluttet i nummer 22. Et av tilfellene tåler å bli gjengitt på nytt det er et merkverdig hendelsesforløp som utspiller seg (Tidsskr Nor Lægeforen 1933; 53: 1202-14).

\section{Om huggsår i rettsmedisinsk praksis. - Drap, selvmord eller ulykkestilfeller ?}

\author{
Av Francis Harbitz, Oslo.
}

(Forts.)

Kasus 5. J. F., 49 år, arbeider ved Ranheim papirfabrikk, bopel Ramstad i Strinda, fantes ved 21-tiden den 16. september 1932 liggende bevisstløs i sitt vedskjul hvortil han gikk ca. kl.19,30 for å hugge ved. Ca. kl. 20 hørtes intet fra vedboden, heller ikke senere. Da han blev lenge borte, lette konen efter ham og fant ham liggende på gulvet i vedskjulet med et stort blødende sår. F. pleiet å holde øksen med høire hånd og veden med venstre.

Han blev funnet i den stilling som perspektivskissen viser, med øksen, som var ca. $60 \mathrm{~cm}$. lang og temmelig tung, halvt skjult under den nederste del av ryggen. Økseskaftet var dekket med blod; på den midtre del av skaftet var der fingermerker. En sag som stod mot en mindre vedstabel, var likeledes oversmurt med blod. Dessuten var der blod flere andre steder (merket med sort).

F. skulde ha lidt av søvnløshet ca. 14 dager. Ved siden av der hvor F. hadde stått og hugget ved, stakk der frem en vedskie ca. $30 \mathrm{~cm}$. fra stabelen, ca. $1,50 \mathrm{~m}$. over gulvet. På dennes ene kant var der et svakt merke efter slag.

Ca. 1,90 m. over gulvet, hvor $\mathrm{F}$. hadde stått, går der en takbjelke. På denne var der flere merker efter øksehammeren. Et av disse merker var antagelig nytt.

På hodet hadde F. en lue hvori det var et stort og 4 små hull. (Det store skyldtes antagelig øksehammeren, de små fall mot sagen).

F. blev straks innlagt i Trondheim sykehus kl. 21,15, men døde ca. $1 / 2$ time efter ankomsten til sykehuset, uten å ha kunnet gi opplysninger.

I hodets isseregion hadde han et sår som begynte ca. 10 $\mathrm{cm}$. ovenfor neseroten. Det var eggformig, ca. $12,5 \times 5 \mathrm{~cm}$., med sagittal akse og med forover noget konvergerende, knuste og blodinfiltrerte rander.

Fortil på høire side hang der en ca. $7 \mathrm{~cm}$. lang hudlapp. Kraniet var slått inn i en utstrekning som var noget mindre enn hudsårets, uten impresjon til sidene, derimot med blodinfiltrert vev i bunnen. I såret fantes bøsspartikler (sagflis ?) og minst 15 benstykker fra enøres til femtiøres størrelse.

Obduksjonen (27. september 1932) blev utført av overlege Fin Holmsen og prosektor N. V. Swensson, som velvillig har stillet tilfellet til disposisjon. Der fantes foruten såret $\mathrm{i}$ bløtdelene et hull i hodeskallens issedel $6 \times 8 \mathrm{~cm}$. stort, med størst lengde i sagittallinjen; videre en plommestor åpning i hjernehinnene, og svarende hertil en knusning av hjernemassen av en fingertupps størrelse i høire hemisfære like ved midtlinjen. De tynne hjernehinner var blodoverfylte, ellers intet å bemerke ved hjernen (spesielt ikke ved lillehjernen, hjernebroen eller den forlengede marg).

Hjertet litt forstørret (v. 450 gr.), - klapper, muskulatur og kransarterier normale. Ved organene for øvrig intet å bemerke.

Konklusjon: Døden skyldes stump vold som med svær kraft har knust issepartiet av hodeskallen, med knusning av hjerne og svær blødning. Det må i tilfelle være øksehammeren som har knust hans hode.

Uttrøndelag politikammer meddeler at efterforskningen menes å ha klarlagt at det foreligger $\mathrm{d} \varnothing \mathrm{d}$ ved u y k ke s tilfelle, ved at øksehammeren er kommet borti vedstabelen baktil således at øksen er glippet og falt ned i hodet på ham.

"Saken gir derfor ikke anledning til nogen forføining.»

Ulykkestilfeller av denne art er visstnok meget sjeldne, - å dømme efter den rettsmedisinske litteratur. Derimot vil det være vel kjent at lesjoner, endog dype og forbundet med svære blodtap, kan være betinget i øksehugg som tilfeldig rammer hodet, endag nakken. Dette ser man især hos tømmerhuggere; et eksempel herpå er referert i min medisinske lærebok av 1926 (side 112 anm.). Men tilfeller av denne art er gjerne oplagte, klare, og har derfor liten rettsmedisinsk interesse. 


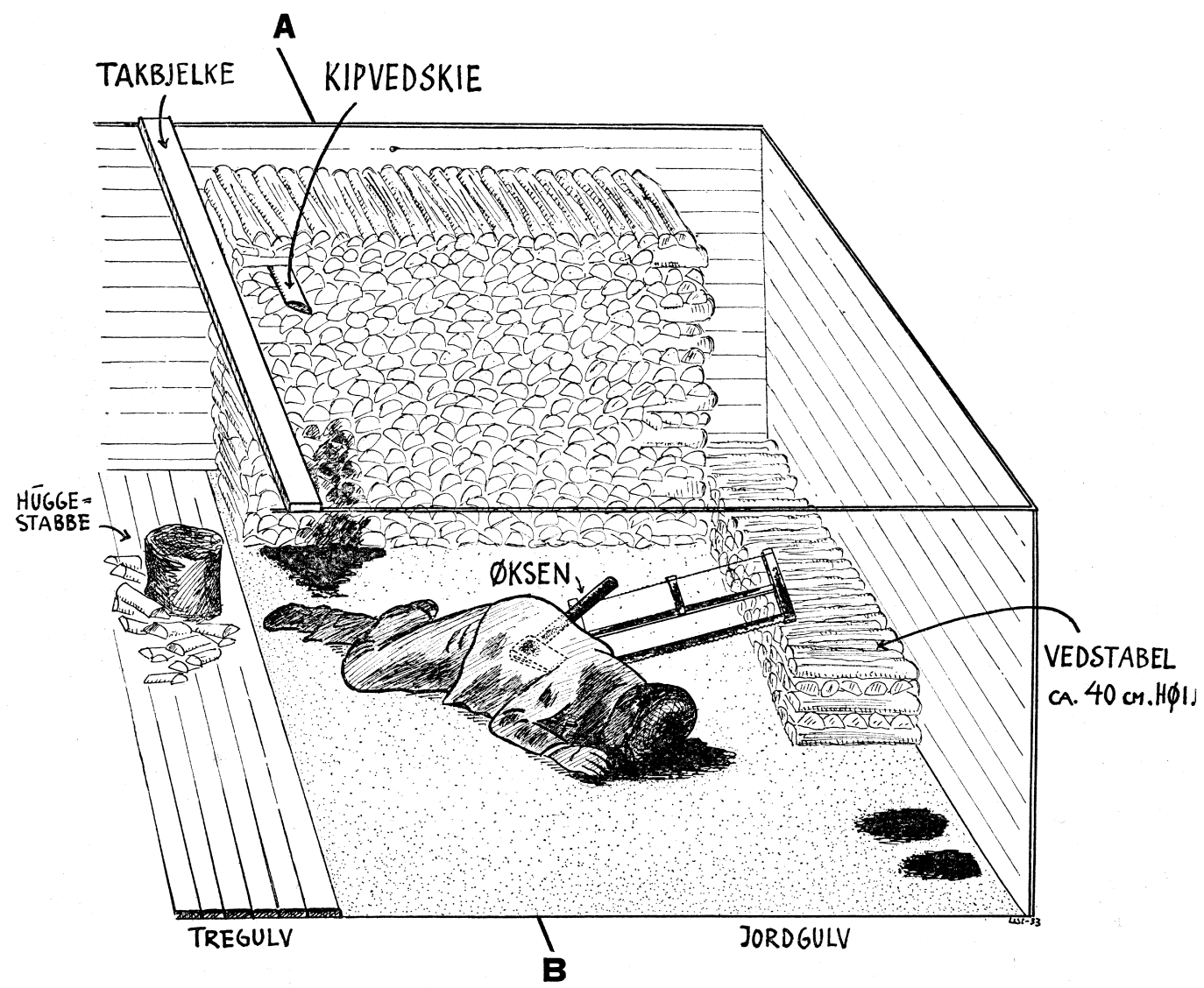

TAKBJELKE

SPOR EFTER OKSEHAMMER

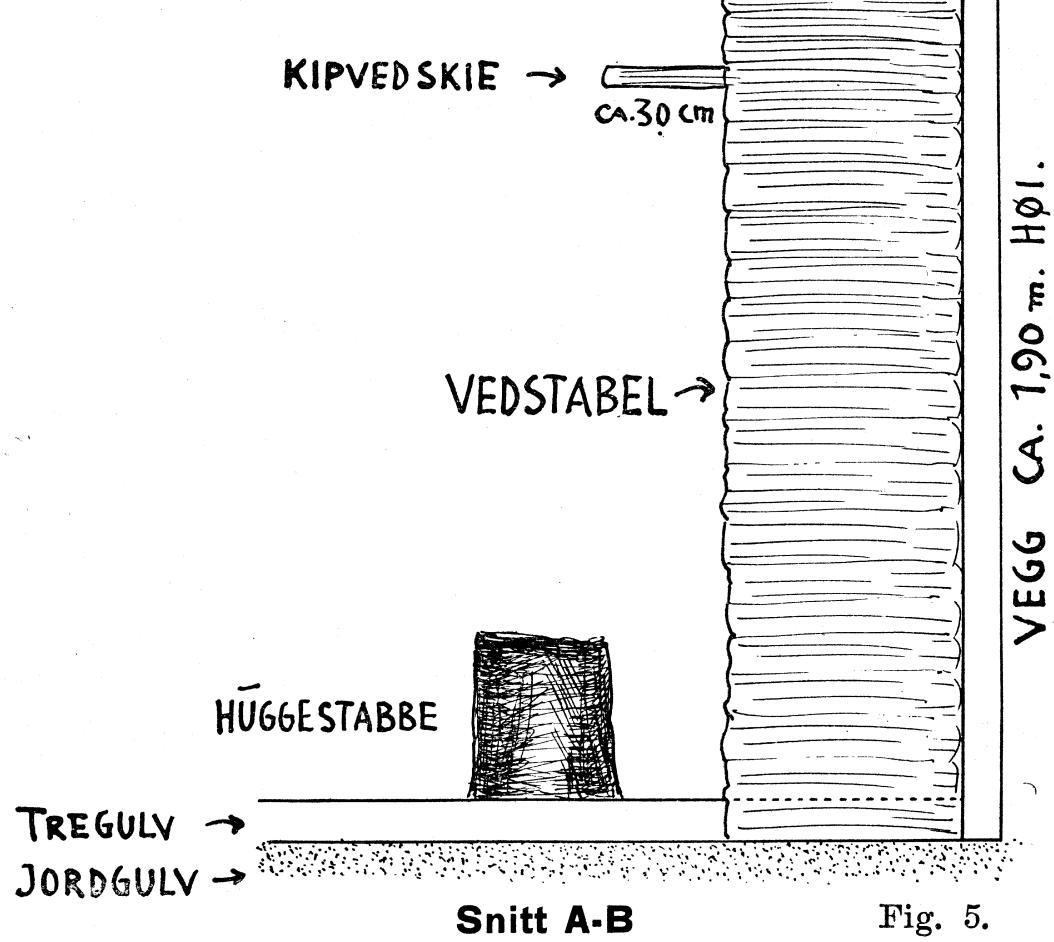

